\title{
Use of Information and Communication Technology (ICT) on Agricultural Marketing in Indonesia A Brief Literature Review
}

\author{
Heri Akhmadi \\ Department of Agribusiness, Universitas Muhammadiyah Yogyakarta \\ Yogyakarta, Indonesia \\ heriakhmadi@umy.ac.id
}

\begin{abstract}
It is obvious that information and communication technology (ICT) have been widely used in agricultural sector in the last decade. Theoretically, ICTs propose to increase the efficiency of agricultural marketing since this could reduce marketing supply chain, thus increasing marketing efficiency. This paper aimed to evaluate the role of information and communication technology used in the agricultural marketing in Indonesia. This study employed historical and systematical review on many articles related to the current development of ICT application. The result showed that mobile phone, SMS, website and social media are the most commonly used ICT tools in agricultural marketing. The study concluded that ICTs play an important role in agricultural marketing by increasing market share and obtaining faster information on price, product and networks.
\end{abstract}

Keywords- Agricultural Marketing, Information and Communication Technology, Literature Review

\section{INTRODUCTION}

Trade liberalization within the framework of free trade in ASEAN such as the ASEAN Free Trade Area (AFTA) and cooperation with Asia Pacific countries in the Asia Pacific Economic Cooperation (APEC) or other free trade agreements has had a significant influence on trade in agricultural sector. The opening of market information not only provides a positive influence for agribusiness entrepreneurs, but this also puts pressure on domestic market by flood of imported agricultural products due to the removal of trade barriers as a consequence of the free trade agreement.

Data from the Ministry of Trade of the Republic of Indonesia show that imports of agriculture commodities, including fruit products during the period of 2016 amounted to 848.1 million US dollars. That number rose around 27.27 percent from the previous period in 2015 amounting to 666.4 million dollars. Meanwhile, imports of vegetable products in the same manner, experienced a significant increase in 2016 to 695.9 million US dollars, an increase of 24.7 percent from the previous period in 2015 of 658.1 million US dollars [1].

The next challenge in agricultural trade apart from trade liberalization is the fast-growing information technology. Recently, the development of information and communication technology (ICT) has rapidly penetrated various sectors of life. Starting from telecommunications as the main sector, followed by other sectors such as industry, trade, education, and transportation as the most controversial sector. Although the application of information and communication technology in agricultural trade is not as fast as that in other sectors such as transportation, sooner or later this will bring significant effect as well.

Information and communication technology have a positive influence on agricultural marketing. The reason for it is that the existence of information technology eases traders in obtaining market information, both product information and customer information, facilitates them in processing the transaction of goods, and reducing costs [2].

However, even though information and communication technology have a positive impact on business, the use of ICTs in business in Indonesia is still limited [3]. There are only a few sectors, such as telecommunication and transportation, whose main contents involve relatively advanced technology. The use of ICTs in agricultural sector especially in terms of agricultural marketing is relatively limited [4].

One of the possible reasons regarding the limited use of information and communication technology in agricultural sector in Indonesia is a low level of information and communication technology development in Indonesia. This can be seen from the development index of information and communication technology in Indonesia, which is still relatively lagging behind other countries in the world. The ICT Development Index data from the International Telecommunications Union, a United Nations agency that examines the development of information and communication technology, show that Indonesia's Development Index of information and communication technology ranks the 111th out of 176 member countries. Indonesia's position in ASEAN is also still quite low, namely number 7 out of 10 ASEAN countries, far below Singapore, Malaysia, even Vietnam, and only superior to Myanmar, Cambodia and Timor-Leste [5].

The low development index of information and communication technology is certainly very unfortunate given the importance of this technology in various sectors of life recently. The ITU data show that the positive potential effect of ICT has not been optimized, especially in terms of agricultural marketing in agricultural sector. Agricultural marketing activities will benefit a lot if they could develop and implement information and communication technology.

Fruit, for instance, is one of perishable agricultural products. Fast distribution of fruit may reduce the risk of losses due to its perishability. By using good information technology, farmers and traders could improve product management. Another possible benefit from the use of information and communication technology is the ease of obtaining customer access [6]. 
The use of information and communication technology in agricultural marketing is an effort that is expected to give a positive impact both for Indonesian farmers and traders in running their business. Using information and communication technology is expected to improve the ease of access to information and effectiveness in product management, expand consumer coverage and ultimately increase the profits of traders. This study aimed to explain the extent of the development of ICT applications in Indonesia, especially in agricultural marketing. It is expected that this study could provide insight regarding the recent development of ICT application in agriculture marketing.

\section{METHODS}

This paper referred to Brady et.al on theoretical method and review of literatures [7]. The method was using explanatory review which means that the keywords used were quite broaden [8].

In order to achieve the objective, this paper examined recently-published studies on the current development of ICT in agricultural sector especially in agricultural marketing from reputable academic sources: Webs of Science, Springer, Emerald Insight, Jstor, Google Scholar etc. This paper only examined sources from the year 2000 until 2018. The year 2000 was determined to be the starting point because it was assumed to be the begining of ICT use in agribusiness [9].

\section{RESULTS AND DISCUSSION}

Information and communication technology (ICT) have various definitions and explanations. The Ministry of Research and Technology of the Republic of Indonesia defines information and communication technology as a part of science and technology which includes technologies related to retrieval, collection (acquisition), processing, storage, dissemination and presentation of information [1]. Included in the definition are all hardware, software, content, and computer infrastructure as well as (tele) communication.

The term ICT (Information Communication and Technology), or among the English-speaking Asian countries referred to as Infocom, emerged after the integration of computer technology (both hardware and software) and communication technology as a means of information dissemination in the second half of the 20th century. The combination of the two technologies is growing very rapidly lately and far beyond other technology fields. Even up to the beginning of the 21 st century, it is believed that the ICT field will continue to grow rapidly, and the saturation point will not have emerged until the next few decades. At the global level, the development of ICT has affected all areas of human life. The penetration of ICT into other technology fields has been so deep that none of the equipment produced by technological innovation has not utilized ICT devices [10].

Agricultural information technology is one of the important factors in production and may lead to certain expected development. Agricultural information is the best application of knowledge that will encourage and create opportunities for development and poverty reduction. Effective integration between ICTs in agricultural sector will lead to sustainable agriculture through gradual preparation of agricultural information, which can provide farmers with useful information for decision-making process to improve their productivity. ICTs can improve farmers' access to market information, production inputs, consumer trends, which positively impact the quality and quantity of their production [11]. Information about marketing, new livestock and plant management practices, plant/livestock diseases and pests, transportation availability, market opportunities, and market prices of agricultural inputs and output is very important for economic production efficiency [12].

The development of information and communication technology has made a real contribution to the development of agricultural information systems, especially as an agricultural communication medium. Although information technology has a very important role in supporting agricultural development, until now farmers in the world, especially in Indonesia, are still not much involved in information and communication technology business. The use of information and communication technology in agricultural development requires education and capacity building because there are still technical skills gaps in terms of electronic business (ebusiness) [4].

\section{A. Agricultural Marketing}

Marketing is a series of economic activities that are carried out to improve or create the economic value of a product. Marketing activities are the link between production and consumption activities. Many experts have various definitions of marketing which may differ from one another. The difference is caused by the points of view used by experts defining marketing. In this marketing activity, exchange activities are central. Exchange is a marketing activity where someone tries to offer a number of goods or services by showing their values in various social groups to meet their needs. Marketing as a human activity is directed to satisfy desires and needs through the exchange process.

Philip Kotler defined marketing as a social and managerial process in which individuals and groups get what they need and want by creating, offering, and exchanging valuable products to others. This definition of marketing relies on a core concept that includes needs, wants, and requests [13].

Companies in carrying out their activities must be efficient in using marketing concepts so as to achieve the expected benefits properly. This indicates that marketing activities within a company must be coordinated and managed in a better way. The philosophy of marketing concept aims to give satisfaction to the desires and needs of consumers. In other words, marketing concept is a business philosophy which states that satisfying consumer needs is an economic and social requirement for the survival of a company [14].

Based on the above definition, there is a consequence, i.e. all company activities must be directed to know the needs of consumers and be able to bring satisfaction in order to make a profit in the long run. Corporate organizations that implement this marketing concept are called marketing organizations. The marketing concept also states that the key to achieving organizational goals is to be more effective than competitors in integrating marketing activities to determine and satisfy the needs of the target market. This marketing concept relies on 
four pillars, namely: target market, customer needs, integrated marketing and profitability.

Today, the concept of marketing is experiencing an increasingly advanced development in line with the advancement of society and technology. Companies are no longer oriented only to buyers, but also to society or people. Such concept is called the concept of community marketing [14].

\section{B. Use of ICT in Agricultural Marketing}

The use of information and communication technology (ICT) in agricultural sector can be called as E-agriculture or E-agribusiness [15]. This application can be found from the upstream agricultural sector (production system) to the downstream sector (agricultural marketing).

Information and communication technology can be used to manage and enrich agricultural information database for both agricultural marketing and production activities, and to shorten the time for technology dissemination to farmers. Especially in the field of marketing, information technology can provide faster online up-to-date price information so that farmers and entrepreneurs can make decisions quickly to develop production strategies and obtain optimal benefits in the market [16].

Research on the role of information and communication technology in agricultural activities, especially in agricultural marketing in Indonesia, was still limited. One of the possible reasons of this situation is the limited application of ICT in agricultural sector. Another reason may be related to the quality of the human resources in Indonesia's agricultural sector. A research by Delima pointed out that farmer's ICT literacy is low [17]. Almost all farmers in the study were not ICT literate, even they did not know how to run computer application.

Moreover, farmers' awareness of the need for information is low [18]. Farmers commonly focus on production activity and get information from secondary sources such as government officer, agricultural extension officer, or trader. However, they are aware that information is important to increase their productivity.

Despite several hurdles among farmers, the application of ICT in agriculture has positive effects for farmers in terms of accessing market information and promoting agricultural products [4]. Farmers could get information about agricultural techniques, production input, and price, as well as post information to promote their products.

Related to the ICT tools, a research by Mulyandari found that mobile phone is the device most widely used by farmers. Although farmers only use mobile phone, their mobile phones already have advanced specifications such as connection to the internet, radio and social media applications. Other ICT devices used are fixed phone, smartphone, computer and computer connected to the internet [4].

The use of ICT in agricultural marketing includes not only hardware but also software. Recent development of software application is the use of social media to promote products. There are many platforms of social media that can be used both by farmers and by traders, among the popular platforms in Indonesia are WhatsApp, Facebook, Twitter, and Instagram [19]. A research conducted on Facebook in modern marketing concluded that Facebook Marketing is one way of marketing via the internet by utilizing the functions available on Facebook social networks. Using Facebook Marketing, entrepreneurs not only carry out business marketing processes, but also communicate with their customers. Facebook Marketing is a modern marketing communication solution [20].

Another form of ICT application is website. Website is a collection of pages in an internet site that is located on a domain and is located on the world wide web (www). Using website, farmers could display information regarding their products and service, including the price and other information, for their consumers and possible business partners. They could also conduct transactions with buyers and suppliers [21].

Moreover, information and communication technology is also used in another form, namely E-commerce. The Ecommerce platform combines website usage as a means to market and inform products sold to consumers. E-commerce offers greater market access with lower marketing costs, resulting in more efficient distribution processes [22].

In general, E-commerce as an ICT platform for agricultural marketing is used in two forms, namely marketplace and marketspace. Using the second form, farmers build a website or blog and display or inform their products as well as conduct transaction [23]. While in the form of marketplace, farmers only use websites that are managed by third parties to market their products on those websites [24].

For farmers, the E-commerce model is preferable since this platform offers two benefits, i.e. marketing efficiency and ease of use without having to manage the website. Farmers who use the marketplace model only need to register to become a member, then they could display their products even conduct transactions with consumers [25]. In addition, farmers could easily use E-commerce applications after only short learning and socialization [26]. This may become one solution to the low use of ICT in agriculture.

Finally, regarding the products, there are several agricultural products from Indonesia that are marketed online using ICT platfoms, for examples bananas [27], crops products [28], chilli [29], shallot, rice, banana and other products [30]. A variety of agricultural products marketed online signifies a progress of the use of ICT in agricultural marketing in Indonesia.

\section{CONCLUSION}

Information and communication technology have a strategic role in Indonesian agricultural marketing activities. Although the application is still limited, several studies show that ICTs have a positive influence on agricultural marketing, including expanding market access due to the availability of extensive information for consumers through the internet. Moreover, information technology applications provide product information in real time and faster price information for both marketers and consumers to make decisions.

This study found that mobile phone, SMS, website and social media are the most commonly used ICT tools in Indonesian agricultural marketing. Another finding is related to a significant development of e-commerce use in agricultural 
marketing. The study concludes that ICTs play an important role in agricultural marketing by increasing the ability to increase market share and get faster information on price, product, and network.

\section{ACKNOWLEDGMENT}

This paper was financially supported by Institute of Research, Publication and Community Service, Universitas Muhammadiyah Yogyakarta. The author thanks all colleagues from the Department of Agribusiness who provided insight and expertise that greatly assisted in conducting the research, although they may not fully agree with all the interpretations/conclusions of this paper.

\section{REFERENCES}

[1] Ministry Of Research And Technology, "Buku Putih. Penelitian Pengembangan dan Penerapan IPTEK Bidang Teknologi Informasi dan Komunikasi Tahun 2005-2025". Jakarta: Ministry of Research and Technology Republic of Indonesia, 2006.

[2] G. Baourakis, M. Kourgiantakis, and A. Migdalas, 'The impact of ecommerce on agro-food marketing', Br. Food J., vol. 104, no. 8, pp. 580-590, 2002.

[3] F. Wahid and L. Iswari, "Adopsi Teknologi Informasi oleh Usaha Kecil Menengah di Indonesia", in National Conference on Information Technology Application (SNATI), 2007, vol. 2007, no. Snati, pp. 7579.

[4] R. S. H. Mulyandari, "Perilaku Petani Sayuran Dalam Memanfaatkan Teknologi Informasi", J. Perpust. Pertan., vol. 20, no. 20, pp. 22-34, 2011.

[5] http://www.itu.int, "ICT Development Index 2017", 2017. [Online], Available: http://www.itu.int/net4/ITU-D/idi/2017/index.html. [Accessed 3-April-2018]

[6] B. L. Martin and E. Abbott, "Mobile Phones and Rural Livelihoods: Diffusion, Uses, and Perceived Impacts Among Farmers in Rural Uganda", Inf. Technol. Int. Dev., vol. 7, no. 4, pp. 17-34, 2011.

[7] M. Brady, M. R. Fellenz, and R. Brookes, "Researching The Role of Information and Communications Technology (ICT) in Contemporary Marketing Practices", J. Bus. Ind. Mark., vol. 23, no. 2, p. .108-114, 2008.

[8] Å. Svenfelt and J. L. Zapico, 'Sustainable food systems with ICT?', in 4th International Conference on ICT for Sustainability (ICT4S 2016), 2016, no. Ict4s, pp. 194-201.

[9] Y. Zeng, L. Wan, and H. Guo, "E-commerce in agri-food sector: a systematic literature review", Int. Food Agribus. Manag. Rev., vol. 20, no. 4, pp. 439-460, 2017.

[10] H. Wibawanto, "Teknologi Informasi dan Komunikasi Konsep dan Perkembangannya", Seminar Tantangan dan Peluang Pembelajaran TI\&K di Sekolah di Jurusan Kurikulum dan Teknologi Pendidikan Fakultas Ilmu Pendidikan, Universitas Negeri Semarang, 10 February 2007.

[11] K. Lokeswari, "A Study of The Use of ICT Among Rural Farmers", Int. J. Commun. Res., vol. 6, no. 3, 2016.

[12] D. P. Lubis, "Pemanfaatan Teknologi Informasi dan Komunikasi Mendukung Pembangunan Pertanian Berkelanjutan", Bogor, Institut Pertanian Bogor, 2005

[13] P. Kotler, V. Wong, A. J. Saunders, and G. Armstrong, "Principles Of Marketing", vol. 53, no. 9. 2013.

[14] B. Swasta and Irawan, "Modern Marketing Management (In Bahasa: Manajemen Pemasaran Modern)", Jakarta, Liberty, 2008.

[15] Soekartawi, "E-Agribusinis Teori dan Aplikasinya", in National Conference on Information and Communication Application (SNATI), 2009, vol. 2007, no. SNATI 2007.

[16] A. G. Matani, "Information Technology Improving Retail Marketing In Agriculture', in International Marketing Conference on Marketing \& Society", , vol. 444604, 2007.

[17] R. Delima, "Analisis Kondisi Dan Kesiapan Masyarakat Tani Di
Daerah Istimewa Yogyakarta Untuk Memanfaatkan TIK Di Bidang Pertanian", in National Conference on Information and Communication Technology Application (KNASTIK), November 2016.

[18] M. Tamba and M. Sarma, "Factors Affecting the Needs of Agricultura Information Among Vegetable Farmers in West Java Province (In Bahasa: Faktor-Faktor Yang Mempengaruhi Kebutuhan Informasi Pertanian Bagi Petani Sayuran Di Provinsi Jawa Barat)", J. Penyul., vol. 3, no. 1, pp. 24-34, 2007.

[19] emarketer.com, "Social Networks Used by Smartphone Users in Indonesia", $2017 . \quad$ [Online], Available: http://www.emarketer.com/Chart/Social-Networks-Used-bySmartphone-Users-Indonesia-April-2017-of-respondents/208536. [Accessed 2-April-2017].

[20] Z. Muttaqin, " Facebook Marketing dalam Komunikasi Pemasaran Modern", Teknol. J. Ilm. Sist. Inf., vol. 1, no. 2, pp. 103-109, 2011.

[21] L. Pendong, R. Molenaar, H. Wullur, and H. F. Pinatik, "Pembuatan Aplikasi E-Commerce Produk Pertanian Berbasis Content Management System (CMS)", COCOS, J. Ilm. Fak. Pertan. Univ. Sam Ratulangi, vol. 6, no. 11, 2015.

[22] T. Suratno, "Sistem Pemasaran E-Commerce Produk Pertanian Berbasis Web Content Management System", Sosio Ekon. Bisnis, vol. 15 , no. 2, pp. 72-79, 2012.

[23] A. Yashinta, "Model bisnis E-commerce Produk Pertanian (Studi kasus pada PT. Limakilo Maju Bersama petani)', J. Manaj. dan Bisnis Performa, vol. XIV, no. 2, pp. 138-151, 2016.

[24] D. Apriadi and A. Y. Saputra, "E- Commerce Berbasis Marketplace Dalam Upaya Mempersingkat Distribusi Penjualan Hasil Pertanian", J. RESTI (Rekayasa Sist. dan Teknol. Informasi), vol. 1, no. 2, pp. 131136, 2017.

[25] R. H. Wuisan, "Analisis Penggunaan E-Commerce Agribisnis Pada Pemasaran Bawang Merah dan Cabai Merah (Studi Kasus Platform Ecommerce Sikumis dan Limakilo)", Institut Pertanian Bogor, 2017.

[26] R. Sengkey, "IbM Pemanfaatan E-Commerce Dalam Memasarkan Hasil-Hasil Pertanian", J. Tek. Elektro dan Komput, vol. 6, no. 3, pp. 111-115, 2015.

[27] Y. Sugiarti, 'Perancangan Sistem Informasi Agribisnis E-commerce Buah Pisang P', J. Agribisnis, vol. 8, no. 1, pp. 71-82, 2014.

[28] E. N. Afifah and Kasmi, 'Implementasi E-commerce Sebagai Media Promosi dan Informasi Komoditas Palawija di Kabupaten Pringsewu', in Prociding KMSI, no. 09, pp. 166-171, 2017.

[29] D. Martini, "Rancang Bangun E-Marketplace Hortikultura Berbasis Web (Studi Kasus di Kabupaten Kolaka)", PHASTI J. Tek. Inform. Politek. Hasmir, vol. 3, no. 2, pp. 40-48, 2017.

[30] T. Suratno, "Sistem Pemasaran E-commerce Produk Pertanian Berbasis Web Content Management System", Sosio Ekon. Bisnis, vol 15, no. 2, pp. 72-79, 2012. 